Terakreditasi: SK No.: 60/E/KPT/2016

Website : http://ejournal.undip.ac.id/index.php/reaktor/

Reaktor, Vol. 17 No. 2, Juni Tahun 2017, Hal. 59-66

\title{
Influence of Organic Loading and Mixing to the Stabilized Leachate COD Removal Using Circulating Anaerobic Reactor
}

\author{
Aghasa*), Qomarudin Helmy, and Mochammad Chaerul \\ Department of Environmental Engineering, Faculty of Civil and Environmental Engineering, Institut Teknologi \\ Bandung, Jl. Ganesha 10, Bandung, 40132, Indonesia \\ ${ }^{*}$ Corresponding author: aghasaa@gmail.com
}

\begin{abstract}
In Indonesia, several leachate treatments were operated with most of the treatments are using conventional anaerobic lagoon system in pre-treatment section. However, most of the treatments still have low organic removal efficiency. In several studies, removal efficiency could be increased through several modifications inside the pond and one of them is by using mixing addition. Therefore, the aim of this study was to compare leachate organic removal efficiency by using mixing and without using mixing modification. This research used 3 kinds of Circulating Anaerobic Reactor (CAR) where $0.5 \mathrm{~kg} / \mathrm{m}^{3} \cdot$ day Organic Loading Rate (OLR) in reactor-1 (with mixing) and reactor-3 (without mixing) and $1.0 \mathrm{~kg} / \mathrm{m}^{3}$.day OLR in reactor-2 (with mixing) were operated inside the reactor. From the results, the organic removal efficiency in reactor-1 was $81.82 \%$, reactor- 2 was $82.22 \%$, and reactor-3 was $41.67 \%$. It can be proven that leachate organic removal efficiency was possible to be increased with the addition of mixing inside the treatment system.
\end{abstract}

Keywords: Circulating Anaerobic Reactor; leachate; mixing; organic loading; removal efficiency

Abstrak

PENGARUH BEBAN ORGANIK DAN PENGADUKAN TERHADAP PENYISIHAN COD LINDI TERSTABILISASI DENGAN MENGGUNAKAN CIRCULATING ANAEROBIC REACTOR. Di Indonesia, pengolahan lindi dioperasikan dengan sebagian besar pengolahan menggunakan sistem kolam anaerobik konvensional pada bagian pre-treatment. Akan tetapi, sebagian besar pengolahan masih memiliki penyisihan organik yang rendah. Dalam beberapa penelitian, efisiensi penyisihan dapat ditingkatkan melalui beberapa modifikasi di dalam kolam dan salah satunya adalah dengan menggunakan pengadukan. Oleh karena itu, tujuan dari penelitian ini adalah untuk membandingkan efisiensi penyisihan organik lindi dengan menggunakan pengadukan dan tanpa menggunakan pengadukan. Pada penelitian ini digunakan 3 jenis Circulating Anaerobic Reactor (CAR) dimana reaktor tersebut dioperasikan dengan Organic Loading Rate (OLR) sebesar 0,5 $\mathrm{kg} / \mathrm{m}^{3} \cdot$ hari di dalam reaktor-1 (dengan pengadukan) dan reaktor-3 (tanpa pengadukan) dan OLR sebesar 1,0 kg/m $\mathrm{m}^{3}$ hari dalam reaktor -2 (dengan pengadukan). Dari hasil penelitian, efisiensi penyisihan organik di dalam reaktor-1 adalah sebesar $81,82 \%$, reaktor-2 sebesar 82,22\%, dan reaktor-3 sebesar 41,67\%. Melalui hal tersebut, dapat dibuktikan bahwa efisiensi penyisihan organik pada lindi memungkinkan untuk ditingkatkan dengan penambahan pengadukan di dalam sistem pengolahan.

Kata kunci: Circulating Anaerobic Reactor; lindi; pengadukan; beban organic; efisiensi penyisihan 
How to Cite This Article: Aghasa, Helmy, Q., and Chaerul, M., (2017), Influence of Organic Loading and Mixing to the Stabilized Leachate COD Removal Using Circulating Anaerobic Reactor, Reaktor, 17(2), 59-66, http://dx.doi.org/10.14710/reaktor.17.2.59-66.

\section{INTRODUCTION}

Solid waste pile inside the final disposal site will experience chemical and biochemical degradation decomposition. When rainwater and surface water absorbed inside the waste's pile, it will produce liquid seepage with high pollutant and very high oxygen demand content called leachate. In general, leachate contains decomposed chemical substances from solid waste and water which seeped inside the waste's pile. The source of water could be from rainwater, drainage, groundwater or any other sources around the final disposal site. Leachate is also rich in ammonia, halogenated hydrocarbon suspended solids, heavy metals, and inorganic salt (Aziz et al., 2010)

In the final disposal site which was still operating, leachate's COD value will be between 3000 and $60000 \mathrm{mg} / \mathrm{l}$ with $\mathrm{pH}$ between 4.5 and 7.5 (Martono, 1996). But, in the final disposal site which have been operated for more than 15 years, generally, there will be a few reduction of $\mathrm{BOD}_{5}, \mathrm{COD}$ or TOC, and even the $\mathrm{pH}$ of leachate tend to be neutral and also, it has other mineral compounds which relatively decreased (Martin and Moshiri, 1994).

In Indonesia, leachate treatment inside the final disposal site have been conducted in the pre-treatment of the final disposal site leachate treatment pond at Sarimukti, Bantar Gebang Jakarta, Sanden Magelang, Grenjeng Cirebon, and Putri Cempo Solo final disposal site. Most of them are using conventional anaerobic lagoon system. Theoretically, anaerobic lagoon in Indonesia, in average, can remove organic parameters (in the form of COD) by $85-90 \%$ with average organic loading $1-2 \mathrm{~kg} / \mathrm{m}^{3}$. day and relatively longer contact time (Damanhuri, 2008). However, from the observation results which have been conducted in several leachate treatment plants, most of them didn't worked properly which can be caused by the inappropriate design criteria and unsystematic operating system.

Several biological processes of wastewater treatments have been conducted in several studies, especially the anaerobic process. The anaerobic systems such as Filter Reactor, Contact Reactor, 2phase Digester, Fluidized Bed, Semi-continuous, and Sequencing Batch Reactor have been proven to be able to have removal efficiency more than $60 \%$. But unfortunately, most of the processes haven't been done before for leachate treatment since it has a lot of complex characteristics.

Therefore, to optimize the pre-treatment of the existing leachate treatment, anaerobic lagoon can be modified by using several modifications and one of them is by adding mixing inside the anaerobic lagoon. Thus, it can minimize the time needed for leachate treatment.

The objective of this research was to determine the optimum condition of leachate treatment using continuous one-staged Circulating Anaerobic Reactor (CAR) with several variations such as Organic Loading Rate (OLR) and mixing variations. And also, to determine the removal efficiency of one-staged CAR to the organic measurements parameters between using mixing addition and without using mixing addition.

\section{MATERIALS AND METHODS \\ Leachate Characteristics}

Initial Characteristics determination was conducted to characterize the contents inside the leachate specifically. At first, sample of the leachate was obtained from Sarimukti landfill leachate treatment pond. Then, measurement of the leachate initial characteristics was done at the influent of the Sarimukti landfill leachate treatment pond and the effluent of the Sarimukti anaerobic lagoon. Initial characteristics, which were measured on the leachate, consist of physical and chemical characteristics such as $\mathrm{pH}$, Temperature, chemical oxygen demand (COD), biological oxygen demand (BOD), total suspended solids (TSS), volatile suspended solids (VSS), total volatile acids (TVA), Total Alkalinity, total kjeldhal nitrogen (TKN), $\mathrm{NO}_{3}, \mathrm{NO}_{2}$, Total Phosphate (TP), and $\mathrm{NH}_{3}-\mathrm{N}$

\section{Seeding Process}

In this phase, bacteria source addition was obtained from Sarimukti landfill leachate treatment pond sludge mixed with the bacteria source from Water Quality Research Laboratory, ITB. After that, the bacteria source was fed with nutrition in the form of $\mathrm{C}$ (obtained from glucose $\left(\mathrm{C}_{6} \mathrm{H}_{12} \mathrm{O}_{6}\right)$ ), $\mathrm{N}$ (obtained from Ammonium Chloride $\left(\mathrm{NH}_{4} \mathrm{Cl}\right)$ ), and $\mathrm{P}$ (obtained from Potassium Dihydrogen Phosphate $\left.\left(\mathrm{KH}_{2} \mathrm{PO}_{4}\right)\right)$. Then the bacteria source was put into the tube shaped anaerobic reactor which has a submersible pump installed inside it to mix the bacteria source.

\section{Acclimatization Process}

Acclimatization was conducted until the COD concentration was stable, where the bacteria already in the mature state and ready to degrade organic contents in leachate. Besides that, when the COD is in the stable condition, $\mathrm{pH}$ inside the reactor will be around 6-8 which is the optimum $\mathrm{pH}$ for bacteria growth.

Acclimatization was conducted 2 times with the first acclimatization using batch system with 0.5 $\mathrm{kg} / \mathrm{m}^{3} \cdot$ day of OLR and 14 days of Hydraulic Retention Time (HRT) and the second acclimatization using batch system with $1.0 \mathrm{~kg} / \mathrm{m}^{3}$. day of OLR and 7 days of HRT. Several parameters such as COD, TSS, $\mathrm{pH}$, and temperature were measured during the first acclimatization process to observe the stability of the bacteria inside the reactor, whereas in the second acclimatization, parameters in the first acclimatization 
still measured. However, in order to observe the possible bacterial activity and also know the potential of the methanogenic bacteria while the leachate treatment producing methane gas, thus parameter such as TVA and total alkalinity was measured in this process.

\section{Biodegradation Phase}

Biodegradation phase was the core of the leachate treatment by using Anaerobic CAR after the acclimatization process in this research. In this phase, by using the acclimatized bacteria, the removal of the leachate organic parameters was conducted in the reactor to treat non-artificial leachate sample taken from the influent of Sarimukti landfill leachate treatment pond.

In this phase, reactor was operated with $5.4 \mathrm{~L}$ of working volume. The process was conducted using 3 kinds of variation which were consist of one variation using mixing with $0.5 \mathrm{~kg} / \mathrm{m}^{3}$.day OLR (reactor-1), one variation was using mixing with 1.0 $\mathrm{kg} / \mathrm{m}^{3} \cdot$ day OLR (reactor-2), and one variation was without using mixing with $0.5 \mathrm{~kg} / \mathrm{m}^{3}$-day OLR (reactor-3) as the representative form of the leachate treatment at Sarimukti landfill leachate treatment anaerobic lagoon which also has the similar 14 days of HRT. Mixing addition process was conducted by using a submersible pump inside the reactor with 2002/s G value.

Parameters measurement were conducted every day on the effluent section of the reactor and several days on the influent of the reactor to control the removal efficiencies from the leachate treatment process that originates from reactor's influent. Several parameters was measured every day during the biodegradation phase to control the leachate treatment condition inside the reactor such as COD, TSS, TVA, Total Alkalinity, $\mathrm{pH}$, and Temperature. Figure 1 below shows the scheme during the biodegradation assay.

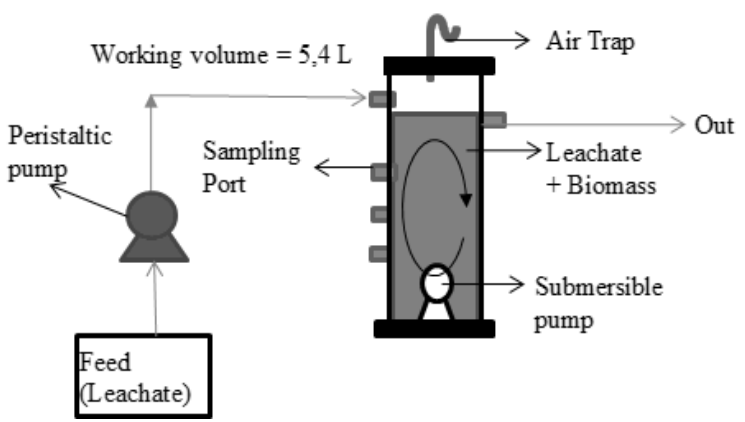

Figure1. Biodegradation phase scheme

Final characteristics measurement was conducted to determine characteristics of the leachate after the process was done. In this phase, some organic parameters from all of the variations were measured in order to be compared with one another. After that, the maximum value of removal efficiency of organic parameters (in the form of COD) during the process was compared with the initial influent condition of the Sarimukti landfill leachate treatment to check the removal efficiency and also to be compared with another research using anaerobic system which have been done previously. The final characteristics parameters, which were measured in this phase, were same as the initial characteristics measurement parameters. Table 1 shows the analysis method for the measurement parameters.

Table 1. Physical-Chemical parameters analysis methods

\begin{tabular}{ll}
\hline \multicolumn{1}{c}{ Parameters } & \multicolumn{1}{c}{ Analysis Method } \\
\hline $\mathrm{pH}$ & $\begin{array}{l}\text { Electrode-Potentiometric SMEWW } \\
4500 \mathrm{H}^{+}\end{array}$ \\
Temperature & SMEWW-2500 \\
$\mathrm{COD}$ & Closed Reflux-Titrimetric SMEWW- \\
& $5220 \mathrm{~A}$ \\
$\mathrm{BOD}$ & Dilution SMEWW 2510A \\
$\mathrm{TSS}$ & Gravimetric SMEWW 2540C \\
$\mathrm{VSS}$ & Gravimetric SMEWW 2540C \\
$\mathrm{TVA}$ & Titrimetric SMEWW-5560C \\
$\mathrm{Alkalinity}$ & Potentiometer Titration \\
$\mathrm{TKN}$ & Destruction-Distillation-Titration \\
& SMEWW-4500 \\
$\mathrm{NO}_{3}$ & Brucin-Spectrophotometry SMEWW- \\
& 4500 NO 3 -AB \\
$\mathrm{NO}_{2}$ & Diazotized-Spectrophotometry Reaction \\
& SMEWW-4500 NO 2 -AB \\
$\mathrm{TP}$ & Acid Titration SMEWW 4500-P-D-B \\
$\mathrm{NH}_{3}-\mathrm{N}$ & Distillation SMEWW 4500-NH 3 BD \\
\hline
\end{tabular}

\section{RESULTS AND DISCUSSIONS}

\section{Leachate Characteristics}

Leachate sample, which was used in this research, was taken from Sarimukti landfill on June $4^{\text {th }}, 2015$. Sarimukti landfill leachate is categorized as a medium stabilized leachate. The other sample was taken from Sarimukti landfill anaerobic lagoon effluent on September $12^{\text {th }} 2015$ as the output of the leachate treatment. Sarimukti landfill leachate initital characteristics shown on Table 2.

Wastewater will be suitable to be treated anaerobically when the wastewater has COD concentration between $3000 \mathrm{mg} / \mathrm{L}$ and $60000 \mathrm{mg} / \mathrm{L}$ (Henry and Heinke, 1996). Thus, Sarimukti landfill leachate, which contains $7.200 \mathrm{mg} / \mathrm{L}$ of COD, was suitable to be treated anaerobically. COD value in Sarimukti landfill leachate realtively high because the samples was taken during the dry season, so that the leachate which was produced from Sarimukti landfill wastes compaction becomes thicker and also had high organic contents. In addition, biological treatment is possible to be conducted if the $\mathrm{BOD} / \mathrm{COD}$ ratio is equal to or above 0,4 (Badkoubi et al., 2002). 
Table 2 Sarimukti landfill leachate initial characteristics

\begin{tabular}{|c|c|c|c|}
\hline \multirow[b]{2}{*}{ Parameters } & \multirow[b]{2}{*}{ Unit } & \multicolumn{2}{|c|}{ Measurement Results } \\
\hline & & Influent & $\begin{array}{l}\text { Anaerobic } \\
\text { Lagoon } \\
\text { Effluent }\end{array}$ \\
\hline $\mathrm{pH}$ & - & 8.1 & 8.2 \\
\hline Temperature & ${ }^{\circ} \mathrm{C}$ & 25.5 & 30.5 \\
\hline COD & $\mathrm{mg} / \mathrm{L}$ & 7200 & 5120 \\
\hline BOD & $\mathrm{mg} / \mathrm{L}$ & 3139.2 & 431.5 \\
\hline TSS & $\mathrm{mg} / \mathrm{L}$ & 1950 & 2696 \\
\hline VSS & $\mathrm{mg} / \mathrm{L}$ & 936 & 1338 \\
\hline TVA & $\mathrm{mg} / \mathrm{L}$ & 344.6 & 307.7 \\
\hline Alkalinity & $\mathrm{mg} / \mathrm{L}$ & 7807.5 & 11711.3 \\
\hline TKN & $\mathrm{mg} / \mathrm{L}$ & 2988.4 & 2121.3 \\
\hline $\mathrm{NO}_{3}$ & $\mathrm{mg} / \mathrm{L}$ & 5.2 & 1.2 \\
\hline $\mathrm{NO}_{2}$ & $\mathrm{mg} / \mathrm{L}$ & 27.3 & 0.0032 \\
\hline ТP & $\mathrm{mg} / \mathrm{L}$ & 25.3 & 25.2 \\
\hline $\mathrm{NH}_{3}-\mathrm{N}$ & $\mathrm{mg} / \mathrm{L}$ & 1720.5 & 1416.4 \\
\hline $\begin{array}{l}\text { Total N- } \\
\text { Organic }\end{array}$ & $\mathrm{mg} / \mathrm{L}$ & 1166.7 & 621.6 \\
\hline $\mathrm{BOD} / \mathrm{COD}$ & - & 0.44 & 0.08 \\
\hline $\mathrm{C}: \mathrm{N}: \mathrm{P}$ & - & 284.6:118.1:1 & $202.8: 84: 1$ \\
\hline
\end{tabular}

According to Tchobanoglous et al. (2003), $\mathrm{C}: \mathrm{N}: \mathrm{P}$ ratio for the nutrition needs for bacteria growth inside anaerobic process is close to 250:50:1. According to the the initial characteristics measurement data, C:N:P ratio in Sarimukti landfill leachate influent was 284.55:118.11:1. Tchobanoglous et al. (2003) also explain that C:P ratio for bacteria inside anaerobic process has 100:1 maximum value. If the ratio were above the standard, then COD removal on leachate will become lower. On Table 2, it can be seen that leachate $\mathrm{C}: \mathrm{P}$ ratio on Sarimukti landfill leachate treatment pond was 284.6:1. Then, after treated inside the anaerobic lagoon, C:P ratio from Sarimukti landfill anaerobic lagoon effluent was decreased to 202.8:1.

\section{Anaerobic Leachate Treatment}

Anaerobic treatment in this research was conducted in 3 phase: seeding, acclimatization, and running.

Seeding was conducted to grow the bacteria which will be used to treat the leachate. In order to be able to examine the bacterial growth, during seeding process, parameters such as COD and TSS were measured. Bacteria growth will consider stable when the COD value is decreasing whilst TSS value increasing until COD and TSS value didn't increase or reduce significantly after several days. Seeding process in this research was conducted in 2 phases in order to increase the bacteria growth.
The process of acclimatization in this research was carried 2 times with $0.5 \mathrm{~kg} / \mathrm{m}^{3}$.day OLR in the first acclimatization and $1.0 \mathrm{~kg} / \mathrm{m}^{3}$.day OLR in the second acclimatization. Acclimatization process was conducted 2 times so that the bacterium was able to adapt while it was fed with leachate. Although the two stage of acclimatization have a different retention time, the acclimatization process will be terminated when the removal of organics in leachate inside the reactor was already stable without significant changes. After the acclimatization process ended, the research was continued to the next phase by conducting the biodegradation phase which was conducted in 3 different reactors.

Organic removal in this research was determined by the value of organic removal efficiency based on the COD value of influent and effluent leachate from CAR. In the measurement of organic removal efficiency, the efficiency increased steadily from the first day until the last day of measurement with the highest efficiency value up to $81.82 \%$.

Inside reactor-1, The value of COD concentration tend to be stable around $1280 \mathrm{mg} / \mathrm{L}$ until $1920 \mathrm{mg} / \mathrm{L}$ after the $8^{\text {th }}$ day of the biodegradation phase. But, in the first few days, the concentration of COD still a little bit fluctuating, where the concentration of COD decreased from day 1 to day 3, then increased slightly in the $4^{\text {th }}$ day, until the steady state was achieved on day-42 with COD concentration of $1920 \mathrm{mg} / \mathrm{L}$. Increased removal of COD concentration was due to an increase in the bacteria activity and organic acids in anaerobic bacteria, such as Bacillus subtilis, to decomposed and digest residual organic in the leachate, while the lactic acid bacteria improve the metabolism of carbohydrates to produce lactic acid and other antimicrobial products, where the antimicrobial products has antimicrobial properties which inhibit the growth of pathogens and unused microorganisms during the process of biodegradation of organic particles in leachate sample (Kamaruddin et al., 2013).

Inside reactor-2, the value of COD concentration reduction tends to be stable, where the value of COD concentration was around $1600 \mathrm{mg} / \mathrm{L}$. The ability of acidogenic bacteria to degrade COD was influenced by the residence time of the liquid. The shorter the residence time of the liquid, the greater the activity of acidogenic bacteria inside the reactor (Ginting, 1993). Therefore, reduction in COD concentration in a short residence time in reactor- 2 can be caused by an increase in organic loading supplied into the reactor, resulting in enhancement of bacterial activity inside the reactor.

In reactor-3, COD concentration relatively constant since the first day. Although there was a slight increase in a few days, the value was still around $4000 \mathrm{mg} / \mathrm{L}$. Compared to the COD in the influent, concentration of COD was declined, although the decline was not significant. COD was increased in several days due to microbial dissolved products 
which contributed in increasing concentrations of COD, where the dissolved microbial products increased the COD through a change of formation of chemical reactions in anaerobic condition (Gashimi, 2009). Due to increased microbial activity that is not matched by equal distribution of bacterial contact with the substrate, it can lead to a little decrease in the value of COD. Figure 2 shows the removal efficiency of COD in all reactors.

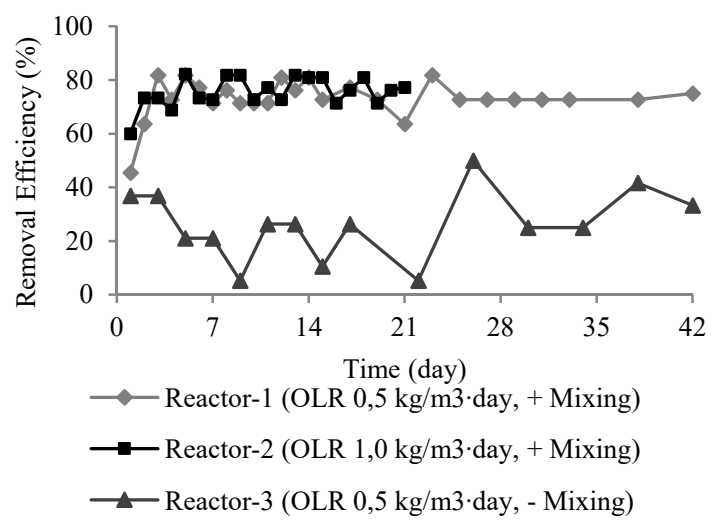

Figure 2. COD removal efficiency during biodegradation phase

The observation results of other physical and chemical parameters inside reactor-1 shows the TSS value tend to fluctuate throughout the process, which on the first day, it tend to be stable at the range of $3000 \mathrm{mg} / \mathrm{L}$. Besides that, the $\mathrm{pH}$ in reactor-1 decreased significantly compared to the influent $\mathrm{pH}$ conditions. However, on day-17 and day-21, $\mathrm{pH}$ was decreased slightly until the $\mathrm{pH}$ value reached 7.3. And then, $\mathrm{pH}$ began to increase again and became stabilized on day-27. The temperature conditions inside reactor- 1 tend to be stable, where the temperature was in the range of 27 to $28^{\circ} \mathrm{C}$. TAV in the reactor tends to fluctuate from day- 1 to day- 25 , and the TAV value began to decline steadily on day27 until day -42 . Total alkalinity inside the reactor-1 tended to increase stably even though the alkalinity was decreased in a few days of the process.

The observation result of other physical and chemical parameters in reactor- 2 shows the value of TSS was increased during the process, which from the first day, TSS effluent concentration was at the value of $2633.06 \mathrm{mg} / \mathrm{L}$ and then increased on the final day until $4018.16 \mathrm{mg} / \mathrm{L}$. $\mathrm{pH}$ condition in reactor-2 was tend to be stable despite the reduction of $\mathrm{pH}$ on day- 8 . After that, it stabilized again on day-13. Temperature in reactor-2 tended to be stable and still in the mesophilic range from $25^{\circ} \mathrm{C}$ to $40^{\circ} \mathrm{C}$. TAV value inside reactor- 2 was increased from day- 6 to day- 10 , and then the value of TAV stabilized on day-11 until the last day of observation. Total alkalinity value inside reactor- 2 tend to fluctuate, which on the first day the value was increase until day-4, then decreased until day-10, and then finally tend to increase again and stabilized on the $12^{\text {th }}$ day until the last day.
The observation result of other physical and chemical parameters in reactor-3 shows the value of TSS in the effluent section was tend to be unstable. $\mathrm{pH}$ conditions in reactor- 3 was quite stable despite a slight decrease on day 5. Afterwards, the $\mathrm{pH}$ stabilized thereafter. Temperature in reactor-3 was increased on day-34 until $30.7^{\circ} \mathrm{C}$ and decrease on the last days. TAV inside reactor-3, although it was fluctuated, the value didn't decrease nor increase significantly. Total alkalinity inside reactor-3 was more stable, but the increased was quite high on the final days with the value of $15354.75 \mathrm{mg} / \mathrm{L}$. Figure 3 shows other physical and chemical parameters conditions during biodegradation phase in all reactors.

After all of the processes were finished, final characteristic measurement was conducted to compare the performance of reactors which were used to determine the optimal conditions in anaerobic process. Table 3 shows the characteristics in all reactors at the end of the process.

Based on observations of the final characteristics of all 3 reactors effluent, the $\mathrm{pH}$ value was still in the range of 6-9, even though it was more alkali, and also with the temperature in mesophilic range $\left(25^{\circ} \mathrm{C}-40^{\circ} \mathrm{C}\right)$. The highest COD removal was occurred in reactor- 2 . Because of the larger organic loading, it can remove larger organic parameters more optimum. According to Kalloum et al. (2012), the high efficiency of COD could be caused by high microbial activity in the reactor. However, if the organic loading was given much higher, there will be the possibility that bacteria can't withstand the given organic loading, so that the instability inside the reactor could be occurred, thus the OLR in the reactor2 can be considered as the optimum OLR in the process. Along with an increase in microbial activity inside the reactor, although the BOD in the three processes also decreased, the ratio of BOD/COD of the three processes is still below 0.4 , where it shows that the bacteria use a small amount of dissolved oxygen in order to remove the organic parameters inside the leachate. From all the 3 reactors, reactor- 3 had the lowest VSS and it was not comparable with the high TSS value. This indicates that the measured TSS was mostly formed from fixed suspended solids (FSS), not from volatile suspended solids. And also, the highest ratio of $\mathrm{C}: \mathrm{N}: \mathrm{P}$ was inside the reactor-3. Inside reactor-1 and reactor-2, despite of the capabilities of the two reactors to remove nitrogen, they still left a lot of nitrogen inside the reactor even though the reactors were already capable on balancing the nutritional needs, in the form of phosphate, for bacteria with C:P ratio below 100:1. According to Mojiri et al. (2012), ammonia would be considered toxic if the concentration exceeds $3000 \mathrm{mg} / \mathrm{L}$, whereas when the concentration is between $1500-3000 \mathrm{mg} / \mathrm{L}$, it will become inhibitors for the anaerobic process in the reactor with a $\mathrm{pH}$ above 7.4 to 7.6. The concentration of ammonia in all three reactors of running were still below $1500 \mathrm{mg} / \mathrm{L}$ which indicates the concentration of 
ammonia in the reactor didn't affect anaerobic treatment process inside the reactor despite the high value of nitrogen which still remained inside the reactor.

From all the three reactors, optimum condition was obtained in reactor-2, where the reactor-2 was using mixing variation and higher OLR which was able to balance the microbial activity inside the reactor

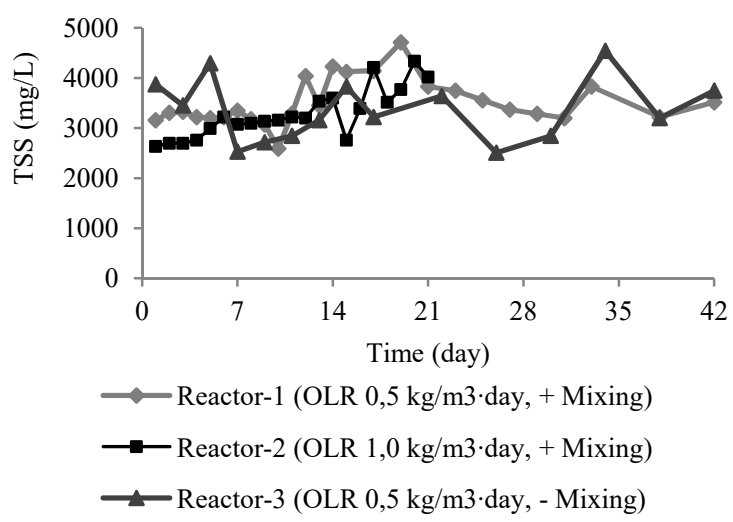

(a)

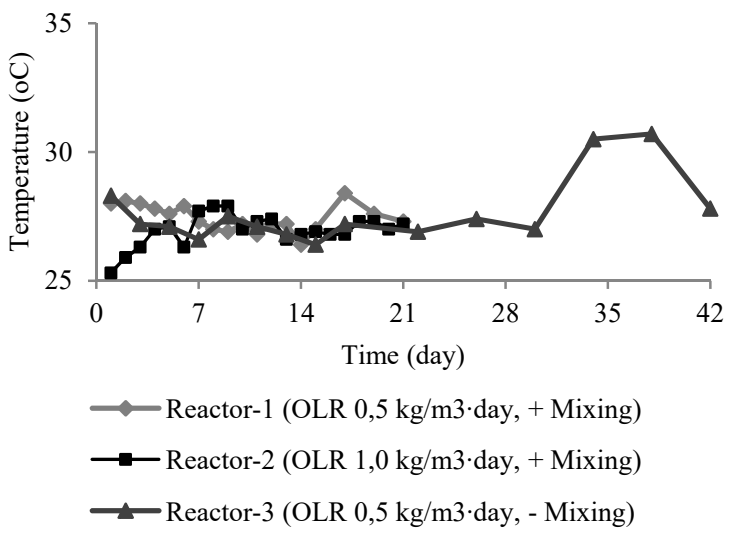

(c) better than other reactors so that the obtained organic removal would be high enough.

From the result, it can be determined that by adding mixing variation, the organic removal efficiency of leachate can be increased. The process was affected by the increase of bacteria contact with leachate inside the reactor. Through that kind of process, bacteria could treat the leachate evenly using anaerobic process.

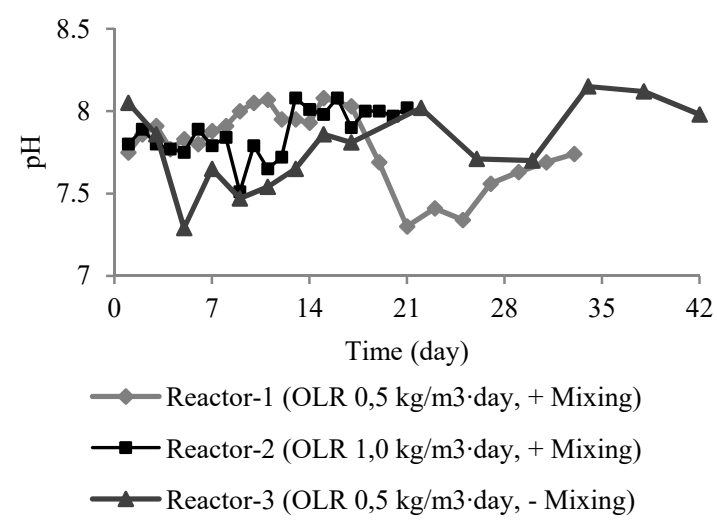

(b)

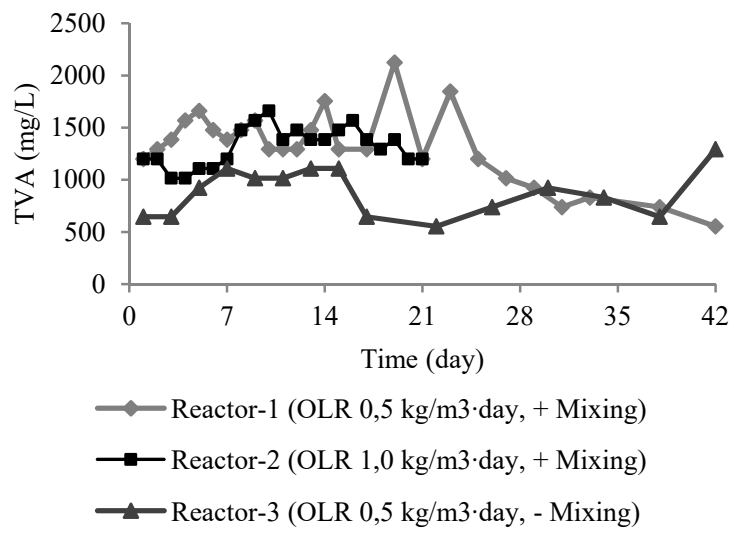

(d)

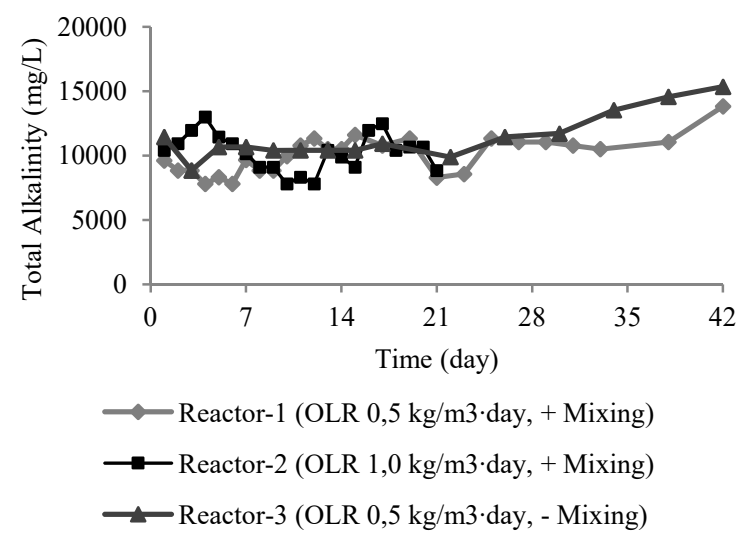

(e)

Figure 3. (a) TSS (b) pH (c) temperature (d) Total Volatile Acids (TVA) (e) total alkalinity condition during biodegradation phase 
Table 3. Reactor effluent final characteristics

\begin{tabular}{|c|c|c|c|c|c|c|c|}
\hline \multirow[b]{2}{*}{ Parameter } & \multirow[b]{2}{*}{ Unit } & \multicolumn{6}{|c|}{ Measurement Results } \\
\hline & & $\begin{array}{c}\text { Reactor-2 } \\
(+) \text { mixing } \\
\text { OLR } 1,0 \\
\mathrm{~kg} / \mathrm{m}^{3} \cdot \text { day }\end{array}$ & $\Pi(\%)$ & $\begin{array}{l}\text { Reactor-3 } \\
\text { (-) mixing } \\
\text { OLR 0,5 } \\
\mathrm{kg} / \mathrm{m}^{3} \cdot \text { day }\end{array}$ & $\eta(\%)$ & $\begin{array}{l}\text { Reactor-1 } \\
(+) \text { mixing } \\
\text { OLR } 0,5 \\
\mathrm{~kg} / \mathrm{m}^{3} \cdot \text { day }\end{array}$ & $\eta(\%)$ \\
\hline $\mathrm{pH}$ & - & 8.02 & - & 7.98 & - & 7.8 & - \\
\hline Temperature & ${ }^{\circ} \mathrm{C}$ & 27.2 & - & 27.8 & - & 27 & - \\
\hline COD & $\mathrm{mg} / \mathrm{L}$ & 1600 & 82.22 & 4480 & 41.67 & 1920 & 81.82 \\
\hline BOD & $\mathrm{mg} / \mathrm{L}$ & 608 & 80.63 & 1045.33 & 66.70 & 276.48 & 91.19 \\
\hline TSS & $\mathrm{mg} / \mathrm{L}$ & 4018 & - & 3744 & - & 3514 & - \\
\hline VSS & $\mathrm{mg} / \mathrm{L}$ & 1944 & - & 1072 & - & 2090 & - \\
\hline TVA & $\mathrm{mg} / \mathrm{L}$ & 1200.00 & - & 1292.31 & - & 553.85 & - \\
\hline Alkalinity & $\mathrm{mg} / \mathrm{L}$ & 8848.5 & - & 15354.75 & - & 13012.5 & - \\
\hline TKN & $\mathrm{mg} / \mathrm{L}$ & 2016 & 32.54 & 2161.57 & 27.67 & 2121.308 & 29.02 \\
\hline $\mathrm{NO}_{3}$ & $\mathrm{mg} / \mathrm{L}$ & 3.72 & 27.93 & 1.09 & 78.85 & 2.79 & 45.87 \\
\hline $\mathrm{NO}_{2}$ & $\mathrm{mg} / \mathrm{L}$ & 0.74 & 97.28 & 0.027 & 99.90 & 0.21 & 99.23 \\
\hline ТP & $\mathrm{mg} / \mathrm{L}$ & 17.22 & 31.94 & 24.43 & 3.43 & 21.10 & 16.60 \\
\hline $\mathrm{NH}_{3}-\mathrm{N}$ & $\mathrm{mg} / \mathrm{L}$ & 826.24 & 51.98 & 1096.78 & 36.25 & 1316.14 & 23.5 \\
\hline Total N-Organic & $\mathrm{mg} / \mathrm{L}$ & 1141.15 & 2.19 & 1000.27 & 14.26 & 727.75 & 37.62 \\
\hline BOD/COD & - & 0.38 & - & 0.23 & - & 0.14 & - \\
\hline$C: N: P$ & - & $92.91: 117.07: 1$ & - & $183.34: 88.46: 1$ & - & 90.99:100.53:1 & - \\
\hline
\end{tabular}

\section{CONCLUSIONS}

Optimum conditions of anaerobic leachate treatment with continuous system using CAR obtained in reactor-2, which when the reactor was operating, the OLR was $1.0 \mathrm{~kg} / \mathrm{m} 3 \cdot$ day with 7 days of HRT. In reactor-2, the organic content in leachate was able to be removed with efficiency up to $82.22 \%$. Through this research, it can be proven that the removal efficiency of organic parameters (in the form of COD) in leachate can be enhanced by adding mixing inside the reactor. Besides that, removal efficiency, in this research, could be increased by increasing the organic loading inside the reactor.

At the end of this research, the authors hope the results could be improved through more specific research related to the characteristics of Sarimukti landfill leachate, where the characteristics of Sarimukti landfill leachate have differences between the dry season and the rainy season because leachate organic content in dry season tend to be more concentrated than in the rainy season. And so, it will be a technical consideration in order to redesign the anaerobic pond in Sarimukti landfill leachate treatment pond if mixing addition was possible to be added. In addition, to complete further studies, the calculation of the velocity gradient ( $G$ value) could be added as a technical consideration in order to design a mixing addition system which will be constructed in an anaerobic leachate treatment plant. Besides that, the further studies can also be done by increasing the variety of stage addition in CAR (whether using twostage or three-stage process) or by adding sludge recirculation process which might increase the removal efficiency of organic parameters in leachate.

\section{REFERENCES}

Aziz, S.Q., Aziz, H.A., Yusoff, M.S., Bashir, M.J.K., and Umar, M., (2010), Leachate Characterization in Semi-aerobic and Anaerobic Sanitary Landfills: A Comparative Study, J Environ Manage, 91, pp. 26082614.

Badkoubi, A., Sarafrazi, M. R., and Stevens, D.K., (2002), Pre and Post Treatment of Landfill Leachate in Vertical Flow Constructed Wetland. ISWA, World Environment Congress, Istanbul, Turkey, pp. 961-968.

Damanhuri, E., (2008), Book of Landfilling Process. Bandung : FTSL ITB.

Gashimi, S.M.D., (2009), Semi-continuous Anaerobic Treatment of fresh Leachate from Municipal Solid Waste Tansfer Station. African Journal of Biotechnology, 8(12), pp. 2763-2773.

Ginting, R. (1993), Kinerja dan Kinetika Bioreaktor Unggun Fluidasi Anaerob (BUFAN) Dua Tahap dalam Mengolah Limbah Cair Pabrik Minyak Kelapa 
Sawit. Thesis, Teknik Lingkungan FTSP ITB. Bandung.

Henry, J.G. and Heinke, G.W., (1996), Environmental Science and Engineering. London : Prentice Hall.

Kalloum, S., Khelafi, M., Djaafri, M., Tahri, A., Kaidi, K., and Touzi, A., (2012), Study of Start-up of a Continuous Digester on a Laboratory Scale Treating The Sludge Issued from Wastewater Treatment Plant in Adrar City (South West of Algeria), Revue des Energies Renouvelables, 15(2), pp. 229-234.

Kamaruddin, M.A., Yusoff, M.S., Aziz, H.A., and Basri, N.K., (2013), Removal of COD, Ammoniacal Nitrogen, and Colour from Stabilized Landfill Leachate by Anaerobic Organism. Appl Water Sci, 3, pp. 356-366.
Martin, C.D. and Moshiri, G.A., (1994), Nutrient Reduction in an In-series Surface-flow Wetlands for Landfill Leachate Treatment, Water Science and Technology, 32, pp. 119-128.

Martono, D.H., (1996), Pengendalian Air Kotor (Leachate) dari Tempat Pembuangan Akhir (TPA) Sampah. Jakarta : Analisis Sistem Badan Pengkajian Penerapan Teknologi.

Mojiri, A., Aziz, A.H.., Zaman, N.Q., and Aziz, S.Q., (2012), A Review on Anaerobic Digestion, Bioreactor and Nitrogen Removal from Wastewater and Landfill Leachate by Bio-reactor, Advances in Env. Biology, 6(7), pp. 2143-2150.

Tchobanoglous, Theisen, and Vigil. (2003). Integrated Solid Waste Management: Engineering Principles and Management Issues. McGraw-Hill. 